This item was submitted to Loughborough's Research Repository by the author.

Items in Figshare are protected by copyright, with all rights reserved, unless otherwise indicated.

\title{
Management and innovation
}

PLEASE CITE THE PUBLISHED VERSION

PUBLISHER

(c) Loughborough University

LICENCE

CC BY-NC-ND 4.0

REPOSITORY RECORD

Papoutsakis, Haris. 2019. "Management and Innovation”. figshare. https://hdl.handle.net/2134/1518. 
This item was submitted to Loughborough's Institutional Repository by the author and is made available under the following Creative Commons Licence conditions.

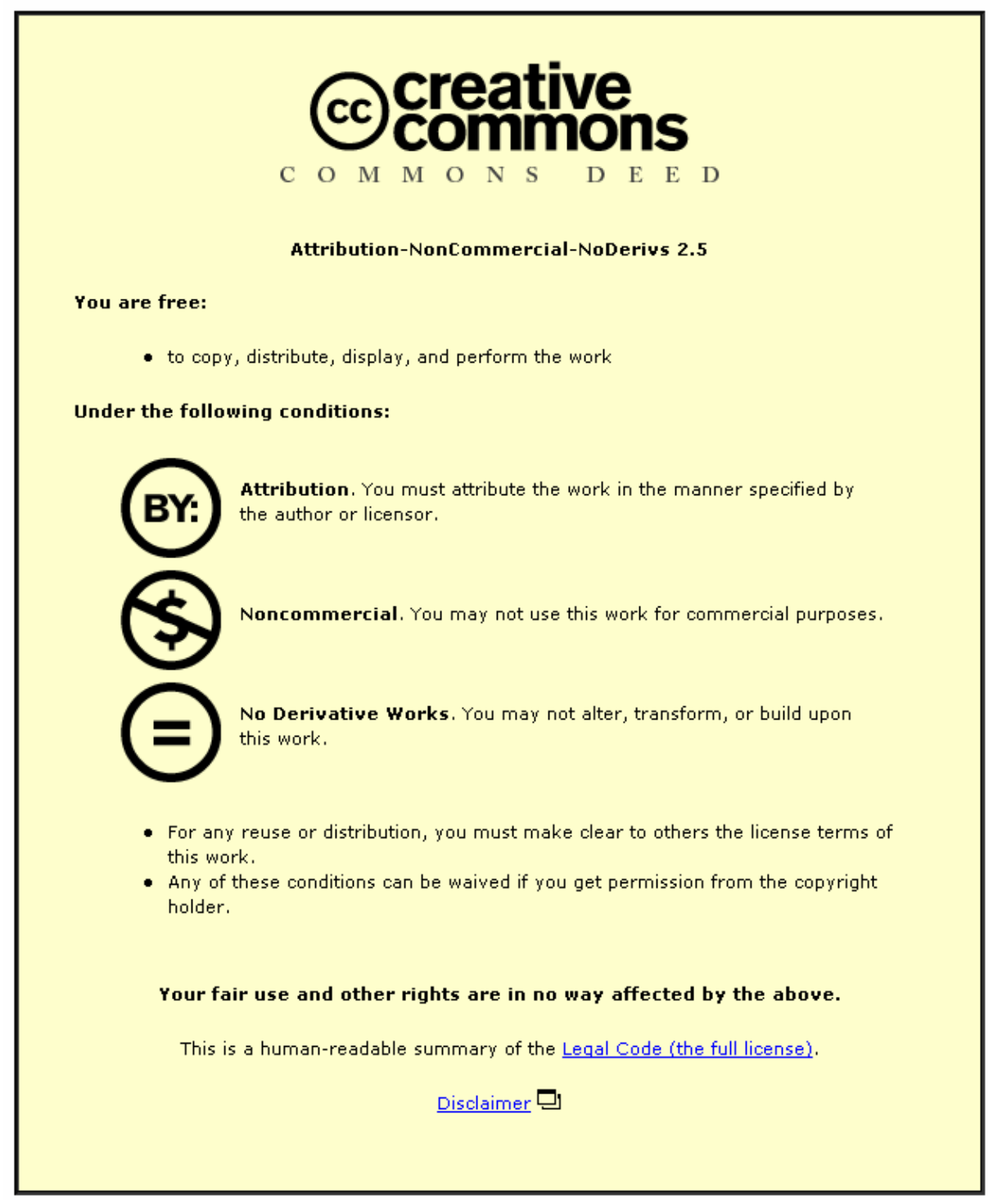

For the full text of this licence, please go to: http://creativecommons.org/licenses/by-nc-nd/2.5/ 


\title{
Management and innovation
}

\author{
Haris Papoutsakis \\ Technological Education Institute, Heraklion, Greece
}

\begin{abstract}
One of the key priorities of creative and realistic management - a today's must for every enterprise - is the continuous search for innovation. Envisaging the future and analysing the market, either in a traditional way or using modern methods like SWOT Analysis, can be of great assistance. They offer a combined knowledge, regarding the company and the business en vironment, it's departments, the productsor servicesand the competition. They help managers to recognise the strong and weak points of their organisation, and to be better prepared to face the opportunities and threats just a head of them. Discipline in strategy, diversified for the different types of businesses, is also important. A unique case study, with more nega tive than positive hints, is quoted.
\end{abstract}

Keywords: Innovation, Envisage, Market Analysis, Present Situation Analysis, Competition, Strengths-Weaknesses-Opportunities-Threats: SWOT Analysis, Combining Stategies, Transforming or Neutralising Strategies, Competitive Situation Analysis, Company Evaluation, Discipline in Strategy, Innovation Musts.

\section{Forecasting}

Too often, profitable companies become comfortable companies and then ... they are no longer profitable

Every person who will be part of the active buying population in the year 2010 has al ready been born. What is then expected from today's businessmen, is to determine now the needs for the year 2010 and make sure they can fulfil most of them. Future trends are of major importance to the way modern business activities are planned long-term.

Forecasting is one of the characteristics corporate leaders (Presidents, Managing Directors or CEO's) are expected to show. But very often in every-day business practice, other staff members from the bottom to the top range of the hierarchy, have proved they can also forecast the future.

\subsection{The telephone}

It was in 1909, when a statistician of the big American telephone company ATT, was studying the statistical diagrams of the American public telephone needs for the previous 15 years. Projection of this data into the near future indicated that by the year 1920, the company should have to employ one telephone operator for every American family using a telephone!
The message was very clear. ATT did not loose any time and within two years the first PABX (Public Automatic Branch Exchange) was available on the market. What followed is known to everybody.

\subsection{Mail Order}

All right answers seem very obvious ... afterwards. As Peter Drucker mentions, everybody believed, around 1900, that a promise of money refunded, following a purchase by mail order, if the customer was not fully satisfied by the product, was not to the company's advantage. The slogan 'satisfaction guaranteed or your money back,' was only going to result in the company's bankruptcy. This did not stop American businessmen Sears and Roebuck starting Mail Order sales, which have today reached enormous turn-overs.

\subsection{Super Markets and Shopping Centres}

It was also known to everybody, around 1925, that people preferred to buy from small specialised shops, spread over the city's market area. Nobody dared propose anything like today's SuperMarkets. Also, everybody knew, until the late 1950's, that people preferred to buy from the city centre. And today we see a very strong trend of both SuperMarkets and Shopping Centres located 
far from the city's centre, and yet attracting the vast majority of the consumers.

\subsection{Mass Media}

What we today call Mass Media would not have been possible, if two major innovations had not have taken place at the end of the last century (around 1890). The first was technological : the printing press that allowed newspapers and magazines to be printed at high speeds, at superior quality and yet at low prices. The second was social-economic : the advertising invasion which started with the "New York Times" and "New York World" as well as the Randolph Hearst's media. Advertising, through marketing mechanisms, provided the media with the funds that allowed them to be sold at reasonably low prices.

\subsection{Polaroid}

Polaroid's success, with built-in photo developing, is an excellent example of a leader's way of thinking. Built-in developing did not answer an existing customer requirement. People were happy with the standard way of film developing after the whole film had been exposed. But the time came when there was an opportunity for innovation and to offer something special in a saturated market. Polaroid was there to maximise this opportunity.

\subsection{Xerox}

Very similar to the above is the case of Rank Xerox. Everybody was more than happy with the 2-3 carbon copies (... and we still use the cc abbreviation!) that every good typist could produce until Xerox, with the new copying machine that was available, which really changed our lives. The innovation, and the created patent have provided Xerox with the dominating leading role in the industry which their competitors have had to fight very hard to keep up with.

\subsection{Robot}

The Japanese are to day's leaders in the Robot industry. The reason : they simply studied very carefully the demographic data of the 1960's. It was obvious then, that there was an increasing trend, for families to offer university education to their children. As a result, the number of workers, who in the 1980's and 1990's would be available for the traditional labour intensive jobs would be dramatically reduced.

Everybody was aware of the phenomena, but it was only the Japanese who took the proper business actions, and they are leading the industry today.

It is obvious from the above, that innovation must not only be the transaction of consumer needs into business opportunities. Over and above this, it has to provide the basis for these needs to be adjusted to a more general development that occurs and which permits a number of ideas, rejected so far, to win broad customer acceptance.

\section{The Market}

Conservative management would prefer the easier and safer way of running a business through established products and methods, instead of being exposed to the rather insecure and expensive new market areas, offering uncertain results. This could well be the case for many enterprises in the last century, or even those of the early 1900's. Could this aspect apply in today's world of increasing competition and economic uncertainty?

Modern companies today have to look for innovation, not only in order to benefit from the results, but for one more, not so obvious benefit it brings. Searching for innovation, and the stimulus that it brings, keeps the entire company in continuous touch with creativity and development. It means a continuous effort to try and benefit from something new.

\subsection{Market analysis}

Analysis for the sake of analysis accomplishes little. Analysis must serve as a basis for action.

Is there a real need for a market analysis? What is the difference between market analysis and the well-known market research? The basic reason for conducting market analysis is to collect, analyse and finally benefit from information, which company management will 
search and identify business opportunities or threats.

Accordingly, these identified opportunities and threats, could in one respect be considered as the limits of the company's expected achievements. It is within these limits that managers have to frame their departmental objectives. In other words, market analysis first aims at a historic study, concerning the market conditions, and then tries to evaluate and locate more effectively the trends and opportunities likely to appear within the time limits of strategic planning.

Market analysis must cover - without always being limited to - the following points:

- an analysis of the present situation

- market potential and limitations

- competition

- the company's strengths and weaknesses

- opportunities and threats

\subsubsection{Present Situation analysis}

An analysis of the present situation can be beneficial in many ways. It helps company management recognise and evaluate more effectively the most important strengths of the company. It allows all management staff, not only to express their contradicting views on a number of proposed innovative ideas but some ideas, previously vague and not fully understood before, to be better understood. Upon accomplishing the analysis, a complete and realistic description of the company's position in its business environment will be available. We will have an answer to the question: "Where do we stand now?"

The analysis, especially when dealing with companies with considerable market shares, has to be extensive so that it covers the social, political, ecological and economical environment of the company. This is what is called the business environment, as opposed to what is usually referred to as the market. The collected data allows management to set the framework into which the company must include it's business activities and targets. In other words, minima and maxima for the company's achievements can be established.

Two historical examples, notable for the failure to analyse the present situation are given. The first has to do with the 1973 oil crisis. It is hard to explain how unready the western industrial world was proved to be to handle the crisis. No one (... or maybe only one of the seven major oil companies) had realised the increased importance oil drilling obtained against the favoured (during the 1960's) oil distillation and distribution. The second is the well-known case of the American car industry, which was terribly late to finally realise the dramatic change in the customers' preference towards smaller sized cars. They had been following a wrong, short term earnings policy, and they almost lost out totally to their Japanese competitors.

\subsubsection{Market potential and limits}

In order to more effectively evaluate the market potential, described above as a business environment, analysis should cover:

a. The total market size as well as the company's sales rate of increase. It is important to know if the rate of sales increases are positive. It could very well be the case that an increase in sales will not be enough. If the total market is also increasing, but at a higher rate then the company is losing its market share.

b. Market segmentation, based on healthy and customer oriented criteria.

c. A number of market characteristics, like seasonal variations, geographic spread and parallel markets where additional sales could be realised.

d. Technological aspect of the market related to the life cycle of the products and the risks from competitors using advanced technology.

e. Preventive measures against unpleasant market situations, such as an economic crisis, a monopoly-type supplier etc.

f. And last but not least, an analysis of previously adapted policies and an evaluation of their results, in an effort to capitalise on successes, to avoid making the same mistakes.

\subsubsection{Competition}

It is in every company's strong interest to build, but also to maintain, a dynamic competitive position in the business environment. Every company should also protect all those strong points which have 
enabled certain market shares for it's products to be gained and significant profits to it's shareholders to be produced. Therefore, the competition analysis should cover:

a. The historical and dynamic presence of all the company's products in their relevant market segments, including statistical data of their performance over certain periods of time, as well as a forecast of their future performance.

b. A comparison of the company's position, versus it's main competitors. Competitors should be analysed both as a whole as well as each one individually. Attention is required on information concerning:

- competitor's market shares (analysed per product, customer or market segments etc.)

- forecast on competitor's changes in strategy

- pricing policy

- service offered (very important for industrial durable products).

The competition analysis should be done very carefully and following rigid rules. Very often, marketing staff tends to overestimate the competition. They have a tendency to recognise benefits and strong points much more than the ones which really exist. They imagine that the competition has better products, better distribution channels, better service and better advertising campaign! Up to a certain extent this is normal and human. But it is also important to have a clear and fair picture of the competition if the company is to benefit from the comparison to follow.

The remaining two points to complete the list set up at the end of paragraph 2.1, in relation to market analysis, have recently earned such a unique importance, that they will be separately analysed in the following paragraph.

\section{SWOT Analysis}

SWOT (Strengths, Weaknesses, O pportunities, Threats) Analysis is an evaluation method of business alertness. In order to draw an effective strategic plan, managers have to adjust their departments objectives, to the available company resources. This could only happen, when the strong and weak points of the company are clearly identified.
Recognising and evaluating the strengths and weaknesses as well as the opportunities and threats, during the business planning process, is called SWOT Analysis, and is illustrated in the following table.

Table 3. SWOT Analysis Matrix

\begin{tabular}{|lcc|}
\hline & PRESENT SITUATION FUTURE SITUATION \\
\hline GOOD & STRENGTHS & OPPORTUNITIES \\
\hline BAD & WEAKNESSES & THREATS \\
\hline
\end{tabular}

According to the application level, SWOT Analysis can be used by experienced staffmembers or managers either to:

1. Analyse the competitive situation of a company department, a product or a service, or

2. Evaluate the overall position of a company or an organisation.

In both cases, the search for innovation is still the primary objective

\subsection{SWOT Analysis of the competitive situation of a company department, a product or a service}

In the course of strategic planning, no matter whether it has to do with a company department, a product or a service, strategic options must be considered. These options can be recognised more effectively by evaluating and controlling both the interior and exterior environment of the company.

It is in this particular area, that SWOT Analysis can be of significant importance. It helps in answering questions like: "Where do we stand now?" and "Where do we want to be?" In the course of this analysis, special emphasis should be given to the extent that the company is both answering its standing against its customer needs, and itsmain competitors.

Due to the simplicity of the method, it is easy for inexperienced staff-members to complete a very vague general SWOT Analysis, contributing very little to the initial requirement. To avoid this, certain rules have to be followed:

a. SWOT Analysis accomplishes very little when applied to a problem as a whole. It is much more effective when focused on certain areas, such as a certain market 
segment, a certain customer group, or a certain competitor.

b. SWOT Analysis is more effective when applied by a team of the company staff. The information collected by a team is always more accurate than anything the most experienced individual could contribute.

c. The analysis must always to be customer oriented especially when analysing strengths and weakness. Any strength or weakness that customers do not recognise as such, or do not consider important, should not be included in the analysis. In this way a company is obliged to think in terms of its customers, which of course is the number one rule of marketers. For example, the vague statement: "We are a big company" proposed as a strength, could be further analysed to the real strengths:

- "We offer a great product mix"

- "Our size, is a guarantee for our customers" but could also result in the following, very important, weaknesses:

- "Bureaucracy"

- Lack of communication, at a personal level, with our customers"

d. Opportunities and threats are only real when they are totally independent of the company environment. That means that they have to be there, whether our company exists or not. There is always the risk that certain staff-members will put into the opportunities "box" their ideas for certain company policies, and thus later manifest as prophets! "Price reduction" is a policy, not an opportunity. Opportunity, in this particular case, is the existence of an unexploited market segment, which is price sensitive.
With the above rules in mind, SWOT Analysis, does allow us to develop two specific strategies, as demonstrated in table 3.1.1.

Table 3.1.1 A customer oriented, SWOT Analysis matrix

\begin{tabular}{|c|c|}
\hline STRENGTHS* & $\longleftarrow$ WEAKNESSES* \\
\hline $\begin{array}{c}\text { Combining } \\
\text { Strategies }\end{array}$ & $\longleftarrow \begin{array}{c}\text { Transforming } \\
\text { Strategies }\end{array}$ \\
\hline \multirow[t]{2}{*}{ OPPORTUNITIES** } & $\longmapsto$ THREATS** \\
\hline & $\longleftarrow \begin{array}{c}\text { Transforming or } \\
\text { Neutralising Strategies }\end{array}$ \\
\hline
\end{tabular}

* Must be recognised by the customer

** Must be independent of the company enviroment

Combining strategies: The emphasis here is to combine the allocated strengths, with the opportunities, offered by the environment. But one should always be aware of the danger if a weakness is combined with a threat. This is an extremely severe situation that must be faced up to.

Transforming or Neutralising Strategies: Attention here is required when examining the weaknesses and threats, in an effort to create strategies that could either neutralise them, or even better, transform the weaknesses into strengths and the threats into opportunities. It is, of course much more difficult developing a transforming strategy.

The following table, gives an example of a SWOT Analysis of the competitive situation of a company department, a product or a service.

Table 3.1.2 SWOT Analysis of the competitive situation

\begin{tabular}{|c|c|c|}
\hline & PRESENT SITUATION & FUTURE SITUATION \\
\hline GOOD & $\begin{array}{l}\text { STRENGTHS } \\
\text { *24 hour service } \\
\text { *Customer tailored services } \\
\text { *Easy approach to company } \\
\text { (parking facilities) }\end{array}$ & $\begin{array}{l}\text { OPPORTUNITIES } \\
\text { *Unexploited Market segments } \\
\text { (i.e. price-sensitive) } \\
\text { *New tax-relief law for } \\
\text { exisiting product }\end{array}$ \\
\hline BAD & $\begin{array}{l}\text { WEAKNESSES } \\
\text { *Not registered TRADE Mark } \\
\text { (Not even well known } \\
\text { among the consumers) }\end{array}$ & $\begin{array}{l}\text { THREATS } \\
\text { *Possible future changes in } \\
\text { Marketing terms with suppliers } \\
\text { * Increase of direct competitors } \\
\text { * Possible economic crisis }\end{array}$ \\
\hline
\end{tabular}


Table 3.2.1 SWOT Analysis for company evaluation

\begin{tabular}{|c|c|c|}
\hline & PRESENT SITUATION & FUTURE SITUATION \\
\hline GOOD & $\begin{array}{c}\text { STRENGTHS } \\
* \text { Capable staff \& } \\
\text { professionals } \\
* \text { Lack of bureaucracy }\end{array}$ & $\begin{array}{c}\text { OPPORTUNITIES } \\
\text { * Creation of new TRADE } \\
\text { Marketing Department } \\
\text { *Unexploited solid assets }\end{array}$ \\
\hline BAD & $\begin{array}{l}\text { WEAKNESSES } \\
\text { * Lack of driving force } \\
* \text { Limited network } \\
\text { of suppliers } \\
* \text { Authoritative Management }\end{array}$ & $\begin{array}{c}\text { THREATS } \\
\text { * Drastic reduction of } \\
\text { R\&D expenditure } \\
\text { * Product in a declining phase }\end{array}$ \\
\hline
\end{tabular}

\subsection{SWOT analysis for company evaluation}

If the requirement is in evaluating a company as a whole, SWOT Analysis can be a valuable tool. However a different approach should be followed. The main differences, from the method described in paragraph above are:

a. The analysis involves the company itself. Not the business environment, or even weaknesses and threats related to customer requirements.

b. The analysis is applied at company level and not concerned with departments, or products or services.

Despite the differences, the team approach is also essential here.

Table 3.2.2 Subjects to be discussed during company investigation
An example of SWOT Analysis for the evaluation of a company, is given in the table 3.2.1 above.

In table 3.2.2, a list of subjects is identified which require further investigation, by applying SWOT analysis for the company evaluation. It is obvious that the list is long, but it only indicates subjects one might have to consider. It is useful to point out that SWOT Analysis by itself, is not enough for a company evaluation. It should only be considered as one of the tools to be used for this purpose, an important tool providing the framework for further analysis and development.

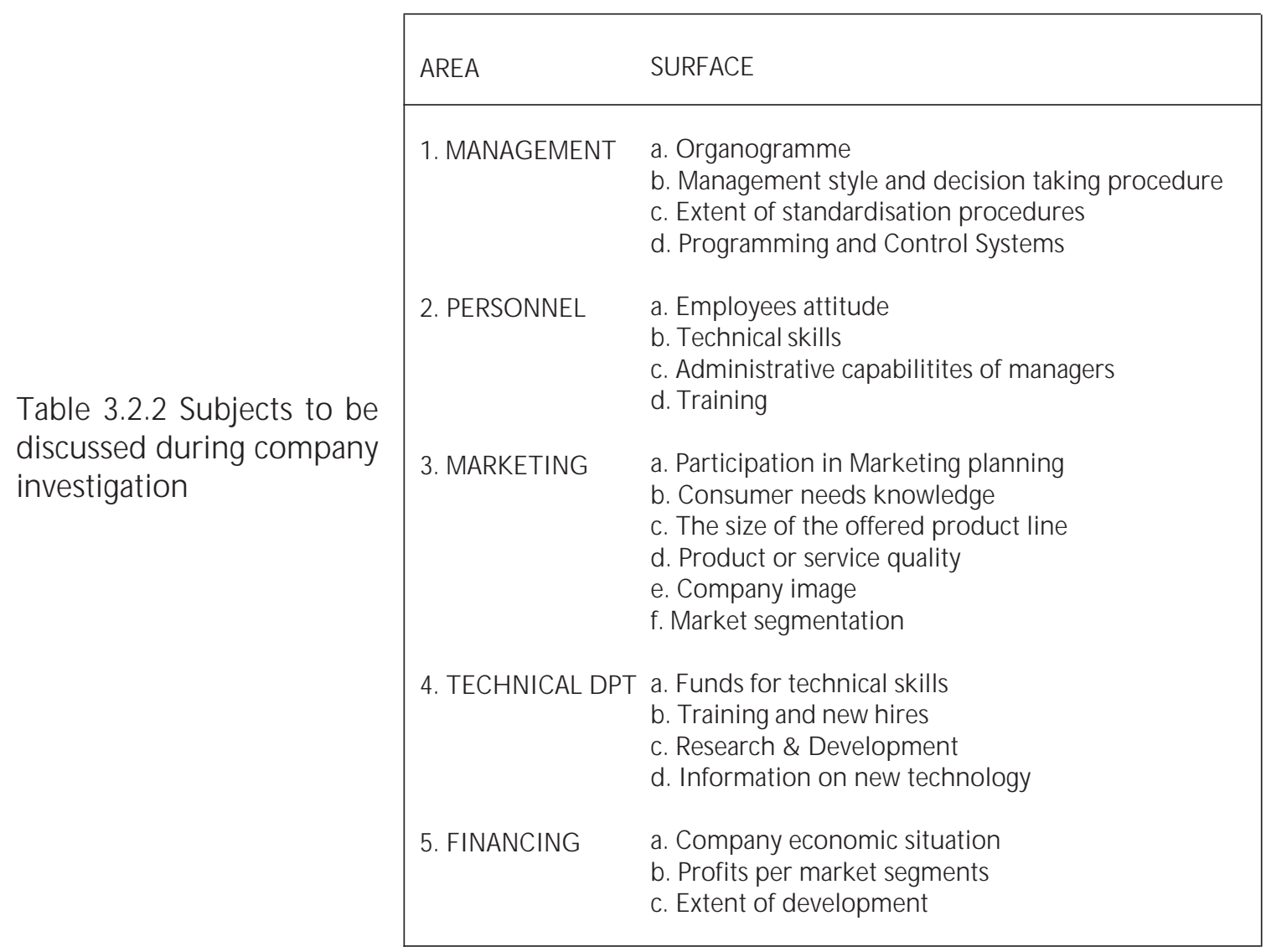




\section{Discipline in Strategy}

It has been emphasised that seeking for innovation, means a continuous effort to try and benefit from everything new, in the company's business area. Of course, this more or less "natural" trend must be controlled, in the framework of company strategies, which, in their turn, are determined by its market position.

It is obvious that multinational corporations, with very big market shares and large product mixes, pay the appropriate attention to the need for innovation. Companies in the area of services, and those in the area of marketing durable or fast moving consumer products, tend to have a different approach towards innovation.

Companies with a very strong leading role in their market, such as IBM or SONY, are not al ways very keen to disturb sales of successful products. They usually wait for their previous investments to fully pay off, before they withdraw them from the market, themselves. On the other hand, they are very interested in every innovation leading to cost reduction, since this is the best way to keep new small competitors out of the market.

The policy described above, in no way means that multinational corporations are not always eager to respond and even push for innovations, when forced by the competition or drastic changes in customer trends.

On the other hand, companies in the area of fast moving consumer products, are continuously searching for new production methods as well as new ways of marketing and distribution. This is exactly the area where marketing innovation, aims to provide better solutions, with imagination and efficiency, to the many changes taking place into the social and economic environments of a company, as well as into its customer buying habits. These habits are marketing and innovation driven. The Mcnair theory for the "Wheel of Retailing" in full action.

The case of companies offering services only, or sometimes products and services, is quite different. Service is an abstract concept, with many invisible elements, which require difficult and expensive market research or even analysis. This is why there is no innovation explosion in their market. Instead of innovation, we notice many ... "limitations" in a strong, competitive environment.

Everybody realises how saturated the Airline market is. Airlines are all offering the same services, under different names, in their efforts to offer something more to their passengers. The same situation is noticed in the Banking or insurance companies area, where most services offered seem to be identical.

Finally, it has to be pointed out, that the starting point for any systematic search for innovation, is the opportunities analysis. Depending on the nature of the innovation, the same opportunities have different importance for different business segments. For example, certain demographic data, could be of minor importance to industries producing industrial Consumer Products (i.e. electric home appliances, food products etc.)

\subsection{The Coca Cola Adventure}

It is worthwhile quoting here the dramatic decision of Coca Cola to change, after 100 years of indisputable leadership, the taste of its product, which had, in the meantime, been converted into a myth, and a symbol with a thousand connections and transactions.

The entire story started with the severe competitive activities noticed between the two major companies, dominating the Cola-type market. When the turnovers involved are that high (it was then a market of $300 \mathrm{M} \$$ ) the rules of the game are different. Even a minor market-shares re-allocation represents a certain danger. So Coca Cola, despite it's leading position, felt insecure.

A very serious preparation procedure, for the introduction of the new taste, had been followed. For almost five years, the company undertook 190000 blind tests, which at a ratio 2 to 1 showed a consumer preference for the new taste. 
Early in May 1985, the effort to promote the new Cola, with a different taste, started in the USA. As soon as the new product replaced the traditional one, consumers reacted in an unexpected way. Within a few weeks, hundreds and thousands of "unhappy" customers kept calling Coca Cola, asking for the old product they all knew and loved. The marketing people were driven crazy, they lost all their sleep, but they could not find a way to convince all these people of the need for change.

So on June 10 of the same year (only a month later) Coca Cola, was forced to announce that the old Coke was soon going on sale again, with the name Coca Cola Classic. The new taste was to be continued, but even this announcement did not stop 600000 complaining telephone calls in the following three months.

So what was all this about? Did the major corporation make a bad decision, instead of a well planned marketing move? All facts lead to the conclusion that the experiment was completely unsuccessful, despite the fact that more than $100 \mathrm{M} \$$ were spent in advertising expenses.

The phenomenon was also analysed by the media. Many American and European magazines claimed that Coca Cola finally failed in convincing its customers of the need for change and thus was forced to take it back. According to "Business Week", the case could be characterised as the public acceptance of an enormous failure in the Marketing era. While others, more politely, referred to it as a quick response and adaptation to consumer preferences.

Some market analysers did not hesitate to call it a well planned strategy, which guaranteed Coca Cola free publicity. The new Coca Cola had been developed, according to them, only in order to stop consumer movement to Pepsi. Roberto Goizueta, the Coca Cola President at the time, was forced to declare that when the company introduced the new taste, he did not intend to continue sales of the old Coke.

Even today, almost ten years later, marketers have not been able to explain the case. The story is not "hot", but the questions are still important. Maybe the best explanation is the one given by the "Financial Times" at the time of the crisis: "Despite the money and the human resources spent in an enormous five years' market and consumer habits' analysis, it was not possible to trace the deep sentimental bond of thousands of Americans with the old Coke."

\section{The Innovation Musts}

\subsection{Simple and Impressive}

For an innovation to be effective and commercially successful, it must be simple and impressive. It must perfectly answer a specific need otherwise it runs into the danger of confusing the average consumer, who generally hates long "user's guides" and special difficulties.

The simplest effectiveness criterion, for given innovation, is to create a first impression, that brings up questions like : "But it's so simple! Why didn't we ever think about that before?"

\subsection{No complicated promises}

Effective innovation must always be introduced in a simple way. It must not be complicated. Customer satisfaction, for a certain need, should easily be recognised through the innovation. Complicated promises, for revolutionary applications, will most probably fail to excite the average consumer.

\subsection{Hard work}

It is not forgotten, that innovation, despite the first impression, is always more work than generating good ideas. There is no doubt that there are certain people, talented in generating innovative ideas. But talent, is not the only ingredient for effective innovation.

Talent, originality and knowledge are the first requirements towards guaranteeing an effective innovation. After that, what is also needed, is systematic hard work. A business man with strong foresight is also required in order to allocate the money and the resources needed to turn a brilliant innovation, into a successful product. 
References

- Drucker F. Peter The Discipline of Innovation, Harvard Business Review, May-June 1985

- Drucker F. Peter Management Harper and Row Publishers

- Kostoulas George Planning, Management 2, Elliniki Evroedotiki, Athens 1986

- Levit Theodor Marketing Imagination, Harvard Business Review bulletin, December 1993

- Piercy N. and Giles W. Making SWOT Analysis work Business school and Strategic Marketing Development Unit, Marlow
- Steiner A George Strategy planning: What Every Manager Must-know N.Y. Free Press, 1989

- Stevenson H.H. Defining Strengths and Weaknesses Sloan Management Review

- Tzortzakis $\mathrm{K}$ and Tzortzakis A Management Athens 1992

- A number of articles from both American (Business Week and Financial Times and Greek (To Vima) newspaper and magazines have provided useful information. 